\title{
Desain EAP Pada Industri Crude Palm Oil Menggunakan TOGAF
}

\author{
Yemima Monica Geasela ${ }^{1}$, \& Johanes Fernandes Andry ${ }^{2)}$ \\ 1)Universitas Bunda Mulia, Jl. Lodan Raya Ancol No. 2, Jakarta 14430 Indonesia, 081254129233 \\ 2)Universitas Bunda Mulia, Jl. Lodan Raya Ancol No. 2, Jakarta 14430 Indonesia, 0818857199 \\ E-mail: yemimageasela28@gmail.com ${ }^{1}$, if_andry@kreavindo.com ${ }^{2}$
}

\begin{abstract}
Abstrak - Industri CPO merupakan sebuah perseroan terbatas yang bergerak dalam bidang penjualan serta pengolah kelapa sawit. Dalam proses peningkatan kualitas dalam pelayanan penjualan dan pengolahan kelapa sawit serta kinerja pegawai, maka diperlukannya sebuah teknologi dan sistem informasi yang dapat membantu dalam proses tersebut. Hal ini dikarenakan pesatnya perkembangan dalam bidang teknologi sekarang ini. Teknologi dan sistem informasi dapat membantu berjalannya serta peningkatan proses bisnis suatu perusahaan jika teknologi dan sistem informasi itu selaras dengan proses bisnis yang ada dalam perusahaan. Industri CPO ini telah mempunyai beberapa aplikasi untuk membantu berjalannya proses bisnis serta meningkatkan kinerja dari pekerjaan industri CPO itu, tetapi perusahaan ini masih membutuhkan beberapa pengembangan terkait teknologi dan sistem informasi mereka terlebih yang berada diperkebunan mereka. Enterprise architecture planning dapat membantu menciptakan teknologi dan sistem informasi selaras dengan proses bisnis perusahaan. Dalam enterprise architecture itu sendiri terdapat beberapa framework pembantu dan pada penelitian ini akan menggunakan framework TOGAF (The Open Group Architecture Framework). Hasil dari penelitian ini berupa usulan model metode TOGAF yang disesuaikan dengan proses bisnis serta kebutuhan bisnis yang ada pada industri CPO yang dapat membantu meningkatkan proses bisnis perusahaan tersebut.
\end{abstract}

Kata kunci: Enterpraise Architecture, TOGAF, Sistem Informasi.

\section{PENDAHULUAN}

Saat ini, dunia telah berkembang dengan pesatnya, begitu pula perkembangan yang terjadi pada bidang teknologi. Perkembangan dalam bidang teknologi itupun menciptakan suatu teknologi informasi yang berkembang pula [1]. Dengan perkembangan teknologi informasi membuat hal ini menjadi salah satu factor dan aspek penting dalam menjalankan serta meningkatkan suatu proses bisnis serta kinerja dari para pekerja bisnis tersebut [2]. Kemampuan perusahaan dalam mengembangkan dan memanfaatkan teknologi informasi menjadi faktor penting untuk dapat memenangkan persaingan [3]. Dengan menggunakan TI/SI yang mendukung proses bisnis suatu perusahaan dapat membuat kinerja yang ada pada perusahaan itu lebih meninggkat sesuai dengan kubutuhan bisnis perusahaan serta meningkatkan daya saing daru perusahaan itu pula [4].

Perusahaan CPO merupakan sebuah perusahaan dimana bisnis mereka bergerak pada bidang pengindustrian agribisnis. Perusahaan CPO ini menyediakan layanan penjualan serta pengolahan dengan bahan baku kelapa sawit. Saat ini, lokasi perkebunan Perusahaan CPO ini berada di Kalimantan Timur, tepatnya di Kabupaten Kutai
Timur, Berau dan Kutai Kartanegara [5]. Saat ini, Perusahaan CPO ini telah menerapkan penggunaan TI/SI untuk mendukung proses bisnis mereka, tetapi masih terdapat beberapa bidang bisnis mereka yang tidak menggunakan TI/SI secara maksimal. Oleh karena itu, masih dibutuhkan beberapa perencanaan TI/SI tambahan untuk mendukung proses bisnis serta pencapaian visi dan misi perusahaan.

Perencanaa TI/SI akan menghambat pencapaian visi dan misi suatu perusahaan jika pengembangan TI/SI pada perusahaan tersebut kurang terencana dengan baik [6]. Peningkatan peran TI/IS nantinya harus berbanding lurus dengan hasil kerja yang dikeluarkan yang biasanya hasil yang dikeluarkan sangat kompleks [7]. Oleh karena itu, dalam perencanaan TI/SI tersebut membutuhkan enterprise architecture untuk membantu dalam penyelarasan perencanaan dengan proses bisnis yang ada.

Dengan ada enterprise architecture, suatu perusahaan dapat membangun suatu TI/SI dengan lebih terarah dan terintegrasi untuk mendukung perusahaan tersebut mencapai tujuan bisnis mereka [8]. Dalam enterprise architecture terdapat beberapa framework pendukung, salah satunya adalah framework TOGAF (The Open Group 
Architecture Framework) yang akan digunakan pada penelitian ini. Dalam proses pembuatan enterprise architecture ini akan dimulai melalui tahap observasi serta wawancara pada perusahaan CPO. Ketika setiap data yang dibutuhkan telah didapatkan maka akan dilakukan analisis dari data-data tersebut menggunakan setiap fase yang ada di TOGAF [9]. Penelitian ini dilakukan untuk membantu perusahaan CPO dalam pengiriman serta penerimaan data kepada perkebunan dari CPO sehingga dapat berjalan dengan lebih terintegrasi.

Hasil akhir dari penelitian ini akan memberikan masukan blueprint aplikasi bagi perusahan sebanyak 6 aplikasi yang diharapkan dapat berguna dalam pengembangan TI/SI pada perusahaan guna meningkatkan kinerja perusahan serta dapat berjalan selaras dengan visi misi dari perusahaan tersebut. Blueprint berupa desain bisnis proses bagi perusahaan CPO dan aplikasi-aplikasi dalam waktu dekat yang akan diimplementasi.

\section{LANDASAN TEORI}

\subsection{Enterprise Architecture}

Menurut Schekkerman, arti dari Enterprise Architecture adalah arsitektur untuk merancang sistem perusahaan. Arsitektur ini melibatkan pemodelan proses bisnis dan karakteristik informasi [10].

Menurut Bernard, arti dari Enterprise Architecture adalah sebuah praktek manajemen dan teknologi yang ditujukan untuk meningkatkan kinerja perusahaan dengan cara melihat perusahaan secara menyeluruh dan terpadu sesuai dengan pandangan arah strategis, praktek bisnis, arus informasi, dan sumber daya teknologi [11].

Berdasarkan dari kedua pengertian Enterprise Architecture diatas, maka dapat disimpulkan bahwa Enterprise Architecture adalah sebuah arsitektur dimana melibatkan proses bisnis dan fitur informasi untuk memajukan kemampuan perusahaan secara merata.

\subsection{TOGAF}

TOGAF (The Open Group Architecture) Framework adalah alat untuk membantu dalam penerimaan, produksi, penggunaan, dan pemeliharaan arsitektur perusahaan. Ini didasarkan pada model proses berulang yang didukung oleh praktik terbaik dan seperangkat aset arsitektur yang ada dapat digunakan kembali [12].

TOGAF adalah kerangka kerja arsitektur, yang memberikan fokus untuk desain, perencanaan, implementasi dan tata kelola EA. Kerangka kerja ini berorientasi pada empat tingkat domain bisnis: Bisnis, Data, Aplikasi, dan Teknologi [13].

Berikut ini adalah langkah-langkah TOGAF berdasarkan gambar 1 TOGAF [14]:

- Preliminary merupakan fase pendahuluan yang menjelaskan tentang kegiatan persiapan dan inisiasi yang diperlukan untuk menemukan arahan bisnis untuk Arsitektur Perusahaan yang baru dan pendefinisian mengenai prinsip-prinssip suatu perusahaan. a. Visi Arsitektur menjelaskan tahap awal Metode Pengembangan Arsitektur (ADM). Pada fase ini akan mencakup mengenai informasi ruang lingkup, dan stakeholder.

b. Arsitektur Bisnis menjelaskan tentang pengembangan Arsitektur Bisnis untuk mendukung persetujuan Visi Arsitektur.

c. Arsitektur Sistem Informasi menjelaskan tentang Arsitektur Sistem Informasi untuk proyek arsitektur baik data maupun aplikasi.

d. Arsitektur Teknologi menjelaskan tentang bagian Arsitektur Data Arsitektur Bisnis.

e. Peluang dan Solusi menjelaskan tentang proses mengidentifikasi kendaraan pengiriman (proyek, program, atau portofolio) yang secara efektif memberikan Arsitektur Target yang diidentifikasi dalam fase sebelumnya.

f. Perencanaan Migrasi menjelaskan tentang bagaimana cara berpindah dari arsitektur saat ini ke Arsitektur target dengan menyelesaikan Rencana Implementasi dan Migrasi yang terperinci. Implementasi Tata kelola menjelaskan tentang menyediakan pengawasan arsitektur terhadap implementasi.

g. Arsitektur Perubahan menjelaskan tentang menetapkan prosedur untuk mengelola perubahan pada arsitektur baru.

- Manajemen persyaratan menjelaskan tentang proses mengelola persyaratan arsitektur di seluruh ADM.

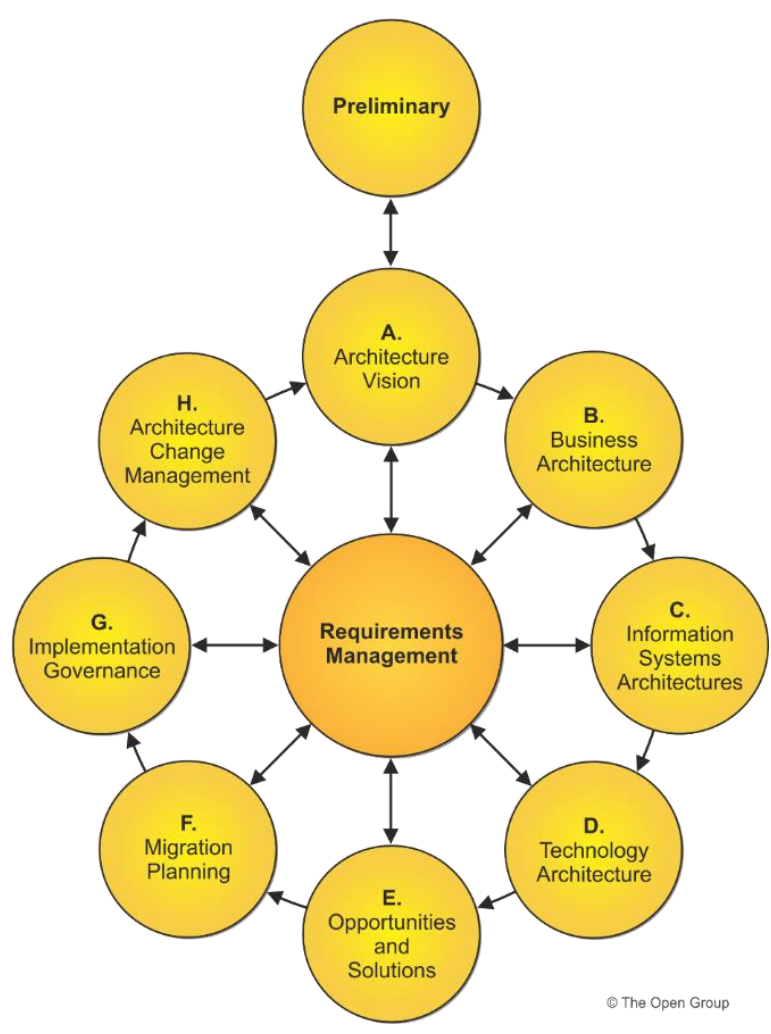

Gambar $1 T O G A F[15]$ 
Berdasarkan dari pengertian TOGAF tersebut maka dapat disimpulkan bahwa TOGAF (The Open Group Architecture Framework) adalah sebuah alat atau kerangka kerja yang digunakan untuk perancangan desain dan tata kelola EA serta digunakan dalam proses pemeliharan arsitektur pada suatu perusahaan.

\subsection{Penelitian Sebelumnya}

Berikut ini adalah beberapa penelitian yang telah dilakukan sebelumnya serta memiliki penggunaan framework yang sama yaitu TOGAF. Penjelasan dapat dilihat pada table 1 penelitian sebelumnya.

Tabel 1 Penelitian Sebelumnya

\begin{tabular}{|c|c|c|}
\hline Nama Peneliti & Judul & Hasil \\
\hline $\begin{array}{l}\text { Gigih Forda Nama, } \\
\text { Tristiyanto, Didik } \\
\text { Kurniawan [16] }\end{array}$ & $\begin{array}{l}\text { An Enterprise Architecture } \\
\text { Planning for Higher } \\
\text { Education Using The Open } \\
\text { Group Architecture } \\
\text { Framework (TOGAF): Case } \\
\text { Study University of } \\
\text { Lampung }\end{array}$ & $\begin{array}{l}\text { Berdasarkan hasil } \\
\text { penelitiannya, peneliti } \\
\text { mengusulkan beberapa } \\
\text { aplikasi penting untuk } \\
\text { dikembangkan yaitu; } \\
\text { SIAKAD-T, E- } \\
\text { PERPUSTAKAAN, } \\
\text { SIPADU-T, DSS, SIPPM- } \\
T, K M S, P M S-T, \text { CRM, } \\
\text { MNC-T, NOPEC-T, SSO, } \\
\text { SISTEM EMAIL. }\end{array}$ \\
\hline $\begin{array}{l}\text { Maulana Ibrohim, } \\
\text { Abba Suganda } \\
\text { Girsang [17] }\end{array}$ & $\begin{array}{l}\text { Designing It Blueprint with } \\
\text { TOGAF For Information } \\
\text { Technology Development }\end{array}$ & $\begin{array}{l}\text { Model arsitektur bisnis } \\
\text { yang direkomendasikan } \\
\text { adalah subproses } \\
\text { dilakukan dengan sistem. } \\
\text { Model arsitektur sistem } \\
\text { informasi yang } \\
\text { direkomendasikan adalah } \\
\text { pengembangan aplikasi } \\
\text { modular. Model arsitektur } \\
\text { teknologi yang } \\
\text { direkomendasikan adalah } \\
\text { menambah dan } \\
\text { memperbarui kualitas } \\
\text { teknologi untuk } \\
\text { mengoptimalkan layanan } \\
\text { teknologi informasi } \\
\text { perusahaan. }\end{array}$ \\
\hline O Herdiana $[18]$ & $\begin{array}{l}\text { TOGAF ADM Planning } \\
\text { Framework for Enterprise } \\
\text { Architecture Development } \\
\text { Based on Health Minimum } \\
\text { Services Standards (HMSS) } \\
\text { at Cimahi City Health Office }\end{array}$ & $\begin{array}{l}\text { Teknologi platform yang } \\
\text { ada saat ini untuk } \\
\text { mendukung kandidat } \\
\text { aplikasi yang diusulkan } \\
\text { tetapi membutuhkan } \\
\text { peremajaan perangkat } \\
\text { keras dan peningkatan } \\
\text { teknologi. } \\
\text { Pemodelan arsitektur } \\
\text { perusahaan ini, } \\
\text { memberikan panduan } \\
\text { dalam membuat cetak } \\
\text { biru untuk pengembangan } \\
\text { sistem informasi untuk } \\
\text { implementasi data HMSS, } \\
\text { aplikasi, bisnis dan } \\
\text { teknologi. }\end{array}$ \\
\hline
\end{tabular}

\section{METODOLOGI PENELITIAN}

Metode penelitian yang digunakan oleh penulis adalah metode deskriptif yang melibatkan studi kasus di industri CPO yang berada di Jakarta. Pada penelitian ini, penulis hanya menggunakan langkah-langkah dari TOGAF seperti fase awal (preliminary), fase A: Arsitektur Visi, fase B: Arsitektur Bisnis, fase C: Arsitektur Sistem Informasi, fase D: Arsitektur Teknologi, fase E: Peluang dan Solusi, dan fase F: Perancangan Migrasi.
Dalam penelitian ini, ada kerangka kerja penelitian yang mencakup seluruh proses penelitian. Penelitian ini dimulai dengan tahap observasi dan wawancara kepada perusahaan terkait dan melakukan analisis terhadap hasil dari setiap data yang diperoleh.

Langkah-langkah ini akan dijelaskan pada gambar 2 berikut:

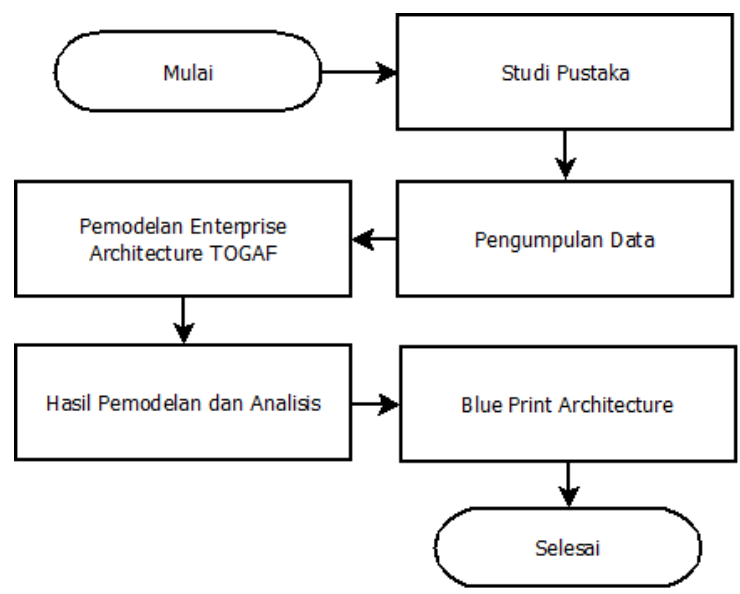

Gambar 2 Langkah Penelitian [19]

Berdasarkan langkah penelitian pada gambar 2 diatas maka dapat dijelaskan sebagai berikut ini:

1. Studi Pustaka. Pengumpulan data-data dari pustakapustaka sebagai referensi yang berasal dari jurnal penelitian, dan informasi lain yang berkaitan dengan penelitian ini. Dalam pengumpulan data dari studi pustaka akan berisikan mengenai enterprise architecture, framework TOGAF, serta beberapa hal yang berhubungan dengan penelitiani ini.

2. Pengumpulan Data. Pada penelitian ini, pengumpulan data dilakukan dengan analisis observasi serta hasil dari wawancara. Wawancara dilakukan pada bagian HRD serta bagian dari Teknologi industry CPO.

3. Pemodelan EA TOGAF. Pada tahap ini akan membahas permodelan dari usulan aplikasi pada penelitian ini menggunakan framework TOGAF sebagai dasar. Tahap ini terdiri dari preliminary phase, architecture vision, business Architecture, information system architecture, serta technology architecture.

4. Hasil Pemodelan dan Analisis. Melakukan analisis dengan menyatukan hasil dari pemodelan TOGAF dan ditentukan yang mana akan dibuat proses pengembangannya.

5. Blue Print Architecture. Membahas mengeneai hasil usulan pengembangan yang telah dianalisis sebelumnya.

\section{HASIL DAN PEMBAHASAN}

\subsection{Analisis Value Chain}

Fungsi model bisnis dalam industri CPO akan dianalisis menggunakan rantai nilai. Value chain ini digunakan untuk menganalisis kegiatan utama dan kegiatan pendukung perusahaan. Value chain sendiri merupakan suatu berntukan 
strategi yang digunakan untuk menganalisis kegiatan internal perusahaan.

Berikut ini adalah rantai nilai dari hasil analisis industri CPO.

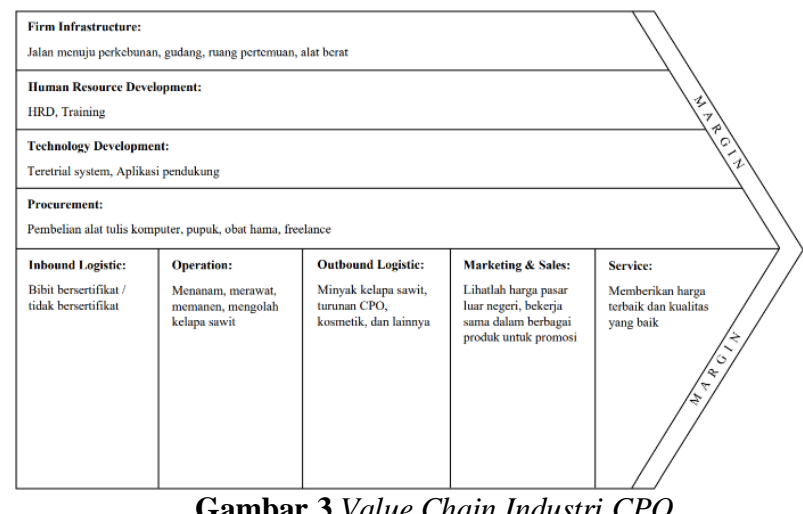

Gambar 3 Value Chain Industri CPO

\section{Aktivitas Utama}

- Inbound Logistic, membeli benih sertifikasi / bukan sertifikasi. benih perkawinan silang atau tidak bersilangan atau benih bersertifikat atau tidak. Pembelian bibit tersebut dilakukan kepada supplier.

- Operasi, Dalam proses operasi di Industri CPO dilakukan setelah pembelian bibit. Bibit yang telah dibeli baik telah disilangkan atau belum dipilih yang terbaik dan kemudian ditanam diperkebunan Industri CPO yang berada di pulau Kalimantan. Sebelum lahan ditanam dengan bibit, lahan tersebut akan dibersihkan dan akan dilakukan pengapuran tanah untuk meningkatkan ph tanah sehingga tersedianya unsur hara pada tanah tersebut. Setelah dilakukan pembersihan dan pengapuran barulah bibit akan ditanam. Setelah bibit ditanam akan dirawat dengan pemberian air, serta pemeliharan bibit dari hama-hama penyakit yang akan mengganggu pertumbuhan bibit. Pemeliharaan dan penanaman bibit ini dilakukan selama 3/5 tahun hingga bibit berubah menjadi pohon kelapa sawit dan mempunyai buah yang siap dipanen berupa buah TBS (Tandan Buah Segar). Setelah buah dari kelapa sawit tersebut siap dipanen, maka pegawai yang ada dilahan kelapa sawit akan melakukan pemanenan kelapa sawit baik menggunakan alat bantu dan tenaga manusia. Dalam pelaksaan panen harus memperhatikan kondisi areal, penyediaan tenaga kerja pemotong buah, pembagian seksi potong buah, serta penyediaan alat-alat kerja. Pemanenan dilihat dari buah yang brondol di tanah dan buah yang masak Buah-buah yang telah dipanen kemudian akan dibawa ke Gudang penyimpanan kemudian barulah dibawa ke pabrik tempat memproses buah-buah kepala sawit yang telah dipanen tersebut. Buah kelapa sawit tersebut akan diolah menjadi minyak kelapa sawit, CPO (Crude Palm Oil) atau pun dapat diolah menjadi kosmetik

- Outbound Logistic, buah-buahan yang dipanen kemudian dibawa ke pabrik tempat kepala buah sawit yang dipanen diproses. Buah sawit akan diolah menjadi minyak sawit, CPO (Crude Palm Oil) atau dapat diolah menjadi kosmetik.

- Pemasaran \& Penjualan, industri CPO memberikan harga dengan harga standar dari pasar luar negeri.

- Layanan, memberikan harga terbaik bagi konsumen serta dengan menjaga kualitas produk yang mereka berikan seperti menggunakan benih unggul, melakukan formulasi tanah dan melindungi pohon kelapa sawit untuk memberikan buah terbaik.

\section{Kegiatan Pendukung}

- Infrastruktur Perusahaan, Firm infrastructure merupakan fasilitas-fasilitas yang disediakan oleh perusahaan. Dalam kontek ini, fasilitas-fasilitas yang disediakan industry $\mathrm{CPO}$ ada jalan keperkebunan dimana jalan ini sangat dibutuhkan untuk mengakses orang yang akan pergi kelahan perkebunan kelapa sawit industry CPO. Akses jalan ke perkebunan ini juga sangat berguna bagi para pegawai yang bekerja di perkebunan yang menjaga setiap pohon kelapa sawit serta mandor yang menjaga setiap pegawa tersebut. Akses jalan ini juga digunakan untuk proses pengangkutan buah panen kelapa sawit sehingga membantuk mengiriman hasil panen ke penyimpanan barang. Dalam proses penyimpanan barang atau hasil panen buah kelapa sawit tersebut, industry CPO menyediakan Gudang penyimpanan untuk hasil panen tersebut, sehingga setiap hasil bauh yang telah dipanen akan dikirim ke Gudang industry.

- Pengembangan Sumber Daya Manusia, menyediakan bagian HRD perusahaan di mana HRD berfungsi untuk mengelola keahlian, meningkatkan dan memotivasi karyawan, dan memberikan pelatihan atau pengembangan bagi karyawan yang kurang mampu meningkatkan kinerja.

- Pengembangan Teknologi, Teknologi yang digunakan oleh Industri CPO antara lain, perusahaan ini menggunakan sistem teresterial dimana teresterial sendiri merupakan sistem yang tidak melibatkan tranmisi satelit tetapi menggunakan gelombang radio melalui pemancar atau antenna. Sistem ini akan membantu melakukan pengiriman informasi dalam jarak jauh karena dapat dilihat keterbatasan jarak antara kantor Industri CPO dengan perkebunan yang miliki oleh perusahaan tersebut. Hal itu membuat sistem ini membantu dalam proses pengiriman data dari perkebunan ke kantor Industri CPO. Beberapa aplikasi pembantu lainnya yang mendukung proses bisnis Industri CPO adalah seperti absensi yang dilakukan menggunakan fingerprint sehingga mambantu mempermudah pegawai dalam proses absensi. Sedangkan, proses absensi yang dilakukan di perkebunan adalah dengan menggunakan BKM yaitu buku kegiatan mandor. Buku tersebut mencatat setiap pekerjaan yang dilakukan diperkebunan, setelah dicatat barulah data-data tersebut dimasukkan ke dalam aplikasi penyimpaan data.

- Pengadaan, mendukung proses bisnis, seperti alat tulis kantor, pupuk untuk menyuburkan kelapa sawit, obat 
hama untuk memberantas hama yang mengganggu pertumbuhan pohon kelapa sawit, serta freelance untuk bekerja membantu di ladang yang membutuhkan bantuan.

\subsection{Interaksi Model Enterprise Planning}

Bagian ini mengacu pada fase E dari TOGAF, Peluang dan Solusi. Bagian ini dimaksudkan untuk mengidentifikasi dan memetakan fungsi bisnis di perusahaan. ada enam sistem akan diimplementasikan, yaitu: sistem situs web company profile, sistem karyawan pengajuan cuti, sistem monitoring barang, sistem penyiraman tanaman, sistem pemetaan tematik, dan sistem pemilihan bibit/pupuk. Implementasi dari sistem tersebut terdiri dari tiga jenis istilah, jangka pendek, jangka menengah, dan jangka panjang. Implementasi jangka pendek dimaksudkan aplikasi yang mendesak dan perlu diimplementasikan dalam waktu singkat, jangka menengah diimplementasikan untuk aplikasi yang tidak terlalu membutuhkan waktu untuk menyelesaikan, dan implementasi jangka panjang untuk aplikasi tidak mendesak tetapi desain aplikasi membutuhkan waktu lebih banyak karena kerumitannya.

- Dalam jangka pendek, terdapat aplikasi website company profile. Dalam website company profile ini akan memberikan informasi mengenai industri CPO, informasi ini meliputi penjelasan mengenai indutri, visi misi, dan informasi lainnya. Sistem monitoring barang yang akan menggunakan RFID sehingga akan lebih menghemat waktu dalam pematauannya.

- Dalam jangka menengah, terdapat aplikasi pengajuan cuti dimana aplikasi ini akan membantu setiap pegawai ketika akan menentukan waktu cuti dan dapat membantu pengurangan kertas cuti. Dalam pengajuan cuti, stakeholder akan menyetujui pengajuan cuti melalui aplikasi pengajuan cuti juga. Sistem pemilihan bibit/pupuk yang dapat membantu industry dalam menentukan bibit dan pupuk yang sesuai dan lebih dibutuhkan.

- Dalam jangka panjang, terdapat aplikasi penyiraman tanaman yang dapat membantu pekerjaan penyiramaan tanama secara automatisasi. Penentuan penyiraman akan tergantung dengan intensitas suhu. Aplikasi peta tematik yang dapat membantu menyimpan letak setiap bibit sesuai dengan jenis bibit masing-masing.

Berdasarkan penjelasan diatas tersebut, penggambaran dari penjelas tersebut dapat dilahat pada gambar 4 Enterprise Planning Model Interaction berikut ini.

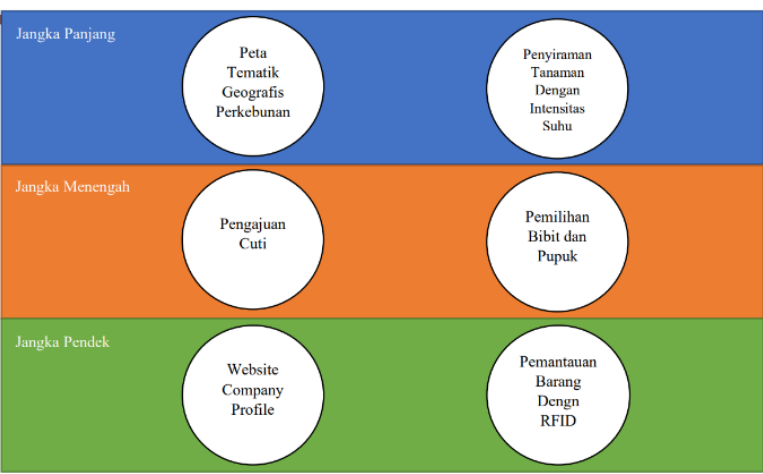

Gambar 4 Enterprise Planning Model Interaction

\subsection{GAP Analisis Arsitektur Bisnis}

Analisis Kesenjangan Arsitektur Bisnis mengacu pada fase kedua TOGAF, Manajemen Kebutuhan. Bagian ini akan menjelaskan kesenjangan analisis bisnis antara arsitektur bisnis saat ini di perusahaan dan arsitektur bisnis target untuk perencanaan masa depan di industri. Arsitektur bisnis saat ini menjelaskan jenis TI apa yang digunakan di industri saat ini dan seberapa besar pengaruhnya di industri. Arsitektur bisnis target menjelaskan perencanaan TI dan TI mana yang harus diimplementasikan di masa depan. Analisis kesenjangan ini dimaksudkan untuk menganalisis kondisi saat ini di industri dan membangun rencana arsitektur bisnis untuk diimplementasikan di masa depan. Lihat pada Gambar 5 berikut ini:

Keterangan:

$$
\begin{aligned}
& =\text { Replace }(\text { Digantikan }) \\
& =\text { Retain }(\text { Dipertahankan }) \\
& =\text { Add }(\text { Ditambahkan })
\end{aligned}
$$

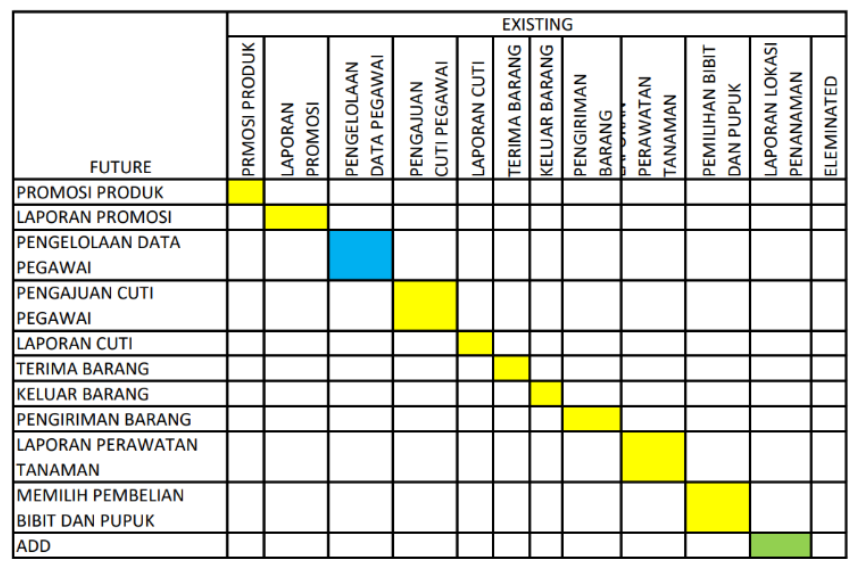

Gambar 5 Gap Analisis Arsitektur Bisnis

Berikut ini akan dijelaskan mengenai Gambar 5 Gap Analisis Arsitektur Bisnis. Berdasarkan Gambar 5 tersebut, dapat dilihat perbedaan dari fungsi bisnis yang lama dengan fungsi bisnis yang akan diusulkan. Dapat dilihat terdapat satu fungsi bisnis yang akan di-retain (dipertahankan) yaitu pada pengelolaan data pegawai. Untuk fungsi bisnis yang akan di-replace (digantikan) yaitu, promosi produk, laporan promosi, pengajuan cuti pegawai, laporan cuti, terima barang, keluar barang, pengiriman barang, laporan perawatan tanaman, serta memilih pembelian bibit dan 
pupuk. Untuk yang di-add (ditambahkan) yaitu fungsi laporan lokasi penanaman.

\subsection{Desain Arsitektur Bisnis}

Dalam membahas desain arsitektur bisnis ini, itu akan mengarah pada diskusi fase B dari TOGAF, Arsitektur Bisnis.

Berikut ini adalah desain arsitektur bisnis yang berjalan saat ini pada insutri CPO yang akan ditampilkan pada Gambar 6 Arsitektur Bisnis Saat Ini.

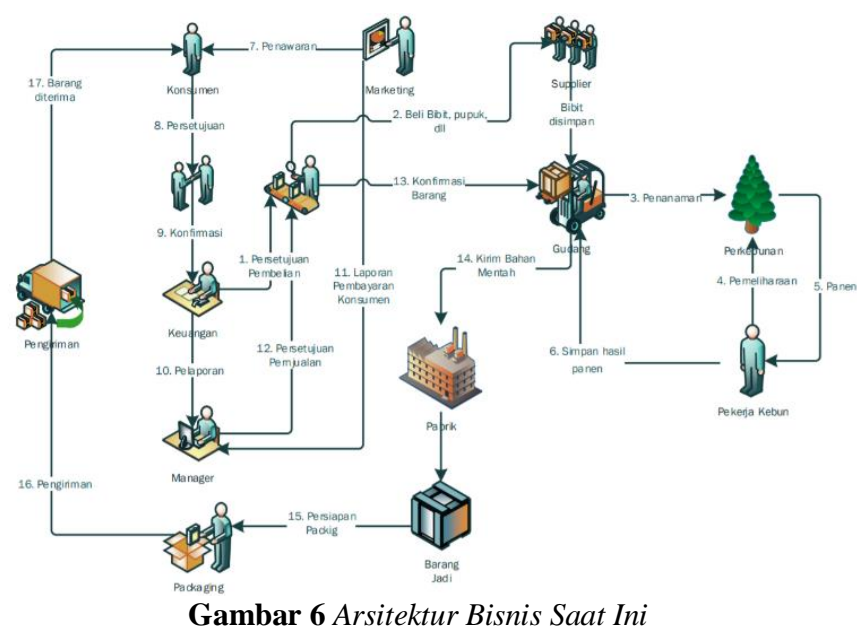

Berdasarkan Gambar 6 tersebut dapat dilihat, bagian keuangan pertama kali akan melakukan persetujuan untuk pemesanan bibit dengan supplier kepada pihak pengadaan. Setelah pihak pengadaan tersebut mendapatkan persetujuan dari pihak keungan untuk melakukan pembelian bibit, maka pihak pengadaan akan membeli bibit dati supplier.

Setelah supplier menerima pesanan dan pembayaran, maka supplier akan mengirimkan bibit tersebut kegudang dari perusahaan. Didalam Gudang tersebut, bibit akan silangkan ataupun tidak disilangkan untuk proses penanaman. Dalam proses penanaman, pekerja perkebunan bertugas untuk melakukan pemeliharaan terhadap bibit yang ditanam tersebut.

Setelah bibit tersebut menjadi kelapa sawit dan siap panen, maka pekerja kebun bertugas untuk melakukan panen terhadap kelapa sawit tersebut lalu dibawa kedala gudang penyimpanan.

Bagian Marketing mempunyai tugas untuk menyebarkan dan mengenalkan mengenai industri $\mathrm{CPO}$ serta memberikan informasi mengenai produk yang dijual oleh industri CPO yaitu kelapa sawit sendiri. Marketing menyebarkan informasi tersebut kepada konsumen dan memberitahukan mengenai cara pemesanan barang. Setelah konsumen melakukan pemesanan, maka konsumen akan melakukan persetujuan pesanan tersebut kepada pbagian keuangan dari perusahaan.

Setelah persetujuan dengan bagian keuangan tersebut telah dilakukan, maka bagian keuangan akan melakukan pelaporan kepada manager mengenai pesanan tersebut. Setelah manager mendapatkan bukti pembayaran konsumen terhadap pesanannya melalui bagian marketing, maka manager akan memberikan pelaporan mengenai persetujuan pembelian tersebut kepada pihak pengadaan.
Setelah pihak pengadaan meneriman surat jalan tersebut, maka pengadaan akan memproses pesanan tersebut mulai dari pengambilan barang dari gudang dan melakukan pengiriman ke pabrik untuk diolah menjadi sesuai dengan pesanan dari konsumen tersebut hingga baramng tersebut jadi dan siap dikemas.

Ketika barang pesanan tersebut telah dikemas, maka bagian packaging akan melakukan pengiriman barang kepada kosumen hingga konsumen menerima barang pesanan mereka

Desain arsitektur model bisnis ini memiliki tujuan yaitu untuk menampilkan setiap proses bisnis dalam industri CPO yang sesuai dengan kebutuhan industri bisnis. Dalam sistem aplikasi ini akan ada enam aplikasi yang akan diusulkan yaitu:

- Profil Perusahaan Web

- Aplikasi Cuti Karyawan

- Pemantauan Barang

- Menyiram Tanaman Berdasarkan Intensitas Suhu

- Peta Tematik Geografis Perkebunan

- Pemilihan Bibit dan Pupuk

Dalam merancang sistem informasi ini akan ada lima aktor yang akan menggunakan aplikasi ini, yaitu pelanggan, akuntansi, HRD, karyawan, dan pekerja kebun. Hal ini dapat dilihat pada gambar 7 Desain Arsitektur Bisnis.

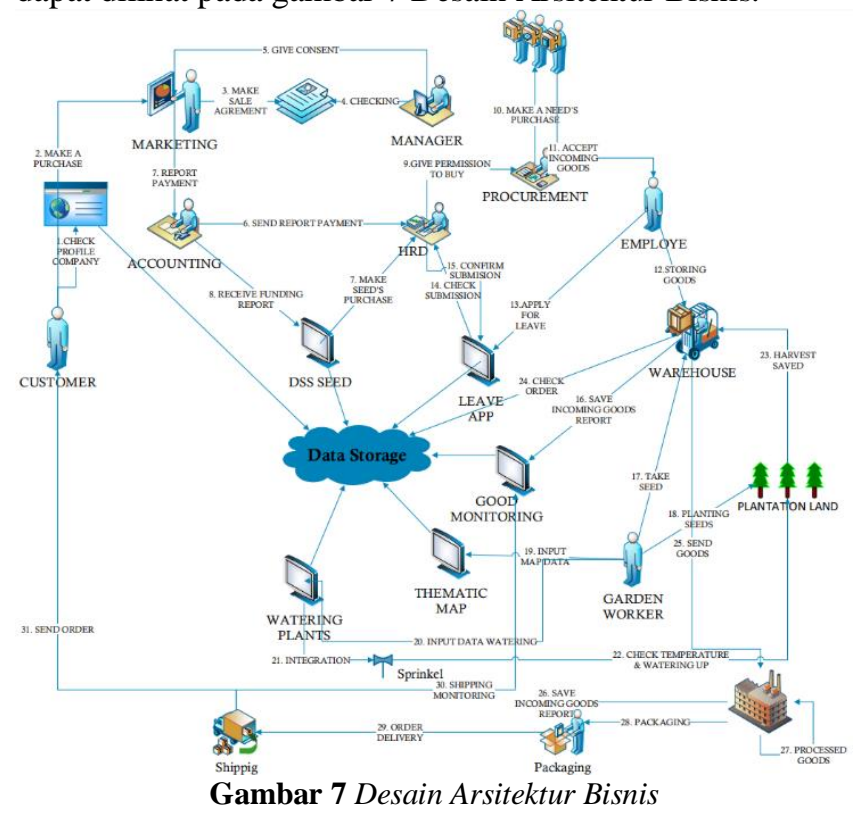

Berdasarkan gambar 7 tersebut, dapat dilihat hasil desain arsitektur bisnis dari usulan aplikasi. Dalam usulan aplikasi tersebut akan terdapat enam aplikasi tambahan:

- Wesite company profile akan berisikan mengenai profile dari industri CPO yang dapat memudahkan pelanggan mencari informasi mengenai industri.

- Aplikasi DSS bibit, aplikasi ini juga akan termasuk dalam aplikasi dss pupuk yang dapat memudahkan perusahaan dalam memilih dan mencari bibit serta bibit unggulan yang tepat untuk digunakan pada industri tersebut.

- Aplikasi pengajuan cuti, dalam aplikasi ini akan membantu pegawai dalam proses pengajuan cuti, hal 
ini dapat meminimalisir penggunaan kertas dalam proses pengajuan cuti.

- Aplikasi monitoring barang, dalam aplikasi ini setiap pengiriman barang baik ke gudang, pabrik, ataupun kepada konsumen akan dimonitoring.

- Aplikasi tematik map, aplikasi ini akan membantu dalam proses penyimpanan data letak bibit yang ditanam sesuai dengan tipe bibit masing-masing.

- Aplikai penyiraman tanaman, dalam aplikasi ini akan membantu dalam proses penyiraman yang dilakukan dengan menggunakan intensitas suhu.

\section{KESIMPULAN}

Berdasarkan hasil diskusi di atas, penulis mendapatkan beberapa kesimpulan dari penelitian sebagai berikut:

- Dalam proses bisnis industri CPO, belum dioptimalkan penggunaan sistem informasi dan teknologi informasi sehingga dalam studi ini desain arsitektur perusahaan dibuat untuk dapat menyelaraskan strategi bisnis dan strategi TI. Desain arsitektur enterprise menggunakan kerangka kerja TOGAF dan menghasilkan cetak biru (blueprint) dari arsitektur utama TOGAF, yaitu arsitektur bisnis, arsitektur aplikasi, arsitektur data, dan arsitektur teknologi.

- Ini memberikan pengembangan aplikasi pengembangan sistem yang baik dan perubahan bisnis yang dapat terjadi jika arsitektur perusahaan diimplementasikan.

- Untuk pengembangan lebih lanjut, ini dapat membuat sistem informasi untuk perkebunan $\mathrm{CPO}$ atau industri perkantoran sehingga dapat lebih mudah dalam proses pengiriman data.

\section{ACKNOWLEDGE}

Terima kasih penulis ucapkan kepada Bapak Husni Hassan yang telah membantu dalam proses.

\section{KEPUSTAKAAN}

[1] J. F. Andry, Y. M. Geasela, A. Wailan, B. A. Matjik, A. Kurniawan, and J. Junior, "Penggunaan COBIT 4.1 Dengan Domain ME Pada Sistem Informasi Absensi (Studi Kasus: Universitas XYZ)," Inform. Mulawarman J. Ilm. Ilmu Komput., vol. 13, no. 2, p. 97, 2019

[2] R. Hariawan, K. R. S. Wiharja, and E. G. Perdana, "Perencanaan Strategis Sistem Informasi Menggunakan TOGAF ADM (Studi Kasus Bagian Pelayanan Barang Pelabuhan Indonesia II)," eProceedings Eng., vol. 1, no. 1, pp. 800-805, 2014.

[3] M. Agarina, "Pemanfaatan Framework TOGAF Untuk Perencanaan Sistem Informasi Manajemen Aset Dan Logistik Di Ibi Darmajaya Bandar Lampung (Studi Kasus : Ibi Darmajaya Bandar Lampung)," J. Inform. Darmajaya, vol. 15, no. 2, pp. 175-187, 2015.

[4] M. Afif, "Perancangan Enterprise architecture Menggunakan Metode TOGAF ADM (Studi Kasus pada PT RMM)," STRING (Satuan Tulisan Ris. dan Inov. Teknol., vol. 2, no. 1, p. 118, 2017.

[5] "palmaserasih.co.id diakses tgl 7 Februari 2019.".

[6] R. Anggrainingsih, A. Aziz, U. Salamah, and S. Widya Sihwi, "Penyusunan Arsitektur Visi dan Arsitektur Bisnis Sebagai Tahapan Perancangan Arsitektur Enterprise Universitas Sebelas
Maret (UNS) Dengan Framework TOGAF," J. Teknol. Inf. ITSmart, vol. 2, no. 2, p. 13, 2016

[7] H. Tamando Sihotang, "Penerapan Tata Kelola Teknologi Informasi Dengan Menggunakan Cobit Framework 4.1 Studi Kasus Pada PT. Perkebunan Nusantara III Medan (Persero)," $J$ Mantik Penusa, vol. 17, no. 1, 2015.

[8] N. Zain, "Pemodelan Arsitektur Enterprise Menggunakan Metode TOGAF ADM (Studi Kasus: SMAN 1

WATUBANGGA)," J. Teknol. Inf. dan Terap., vol. 5, no. 1, pp. $1-8,2019$.

[9] D. P. Kurniawan, Y. A. Prasetyo, and R. Mulyana, "Perancangan It Master Plan Pada Fungsi Teknik Perum Damri Bandung Menggunakan Togaf Adm Designing It Master Plan in Damri Engineering Function Bandung," eProceedings Eng., vol. 5, no. 1, pp. 1445-1452, 2018.

[10] Suryadi and J. F. Andry, "Perancangan Enterprise Architecture Mengunakan Togaf Architecture Development Method ( Studi Kasus : Yakuza Gym Jakarta Barat )," Pros. Semin. Nas. Teknok, vol. 2, no. 2502, pp. 137-150, 2017.

[11] R. Indriani, Murahartawaty, and R. Hanafi, "Analisis dan Perancangan Technology Architecture Menggunakan The Open Group Architecture Framework Architecture Development Method (TOGAF ADM) Pada PT Shafco Multi Trading," eProceedings Eng., vol. 2, no. 2, pp. 1-6, 2016.

[12] R. Harrison, "TOGAF TM 9 Foundation Study Guide," Bus. Manag., p. 243, 2009.

[13] A. Cabrera, M. Abad, D. Jaramillo, J. Gómez, and J. C. Verdum, "Definition and implementation of the enterprise business layer through a business reference model, using the architecture development method ADM-TOGAF," Adv. Intell. Syst. Comput., vol. 405, pp. 111-121, 2016.

[14] R. E. Riwanto and J. F. Andry, "Enterprise Architectures Enable of Business Strategy and IS/IT Alignment in Manufacturing using TOGAF ADM Framework," Int. J. Inf. Technol. Bus., vol. 1, no. 2, pp. 1-2, 2019 .

[15] M.- Mei Mei and J. F. Andry, "The Alignment of Business Process In Event Organizer And Enterprise Architecture Using TOGAF,” JUTI J. Ilm. Teknol. Inf., vol. 17, no. 1, p. 21, 2019.

[16] G. F. Nama, Tristiyanto, and D. Kurniawan, "An enterprise architecture planning for higher education using the open group architecture framework (togaf): Case study University of Lampung," Proc. 2nd Int. Conf. Informatics Comput. ICIC 2017, vol. 2018-Janua, pp. 1-6, 2018.

[17] M. Ibrohim and A. S. Girsang, "DESIGNING IT BLUEPRINT WITH TOGAF FOR INFORMATION TECHNOLOGY DEVELOPMENT," Int. J. Mech. Eng. Technol., vol. 10, no. 3, pp. 837-854, 2019.

[18] O. Herdiana, "TOGAF ADM Planning Framework for Enterprise Architecture Development Based on Health Minimum Services Standards (HMSS) at Cimahi City Health Office," IOP Conf. Ser. Mater. Sci. Eng., vol. 407, no. 1, 2018.

[19] S. Entas, "Perancangan Arsitektur Enterprise Untuk Perguruan Tinggi Swasta Menggunakan TOGAF ADM (Studi Kasus STP Sahid Jakarta)," Paradigma, vol. XVIII, no. 1, pp. 67-78, 2016. 